\title{
A new Eocene free-living cheyletid mite from Baltic amber
}

Andre V. Bochkov and Ekaterina A. Sidorchuk

Acta Palaeontologica Polonica 61 (4), 2016: 869-874 doi:http://dx.doi.org/10.4202/app.00244.2016

A new species of predaceous mite, Cheletomimus (Hemicheyletia) crinitus sp. nov. (Acariformes: Cheyletidae), is described from Eocene Baltic amber based on a fossil female. Among species of the genus, it belongs to the $C$. $(H$.) wellsi species group (16 extant species) and differs from the closely morphologically related species, $C$. greenwoodi by the following features. In $C$. crinitus sp. nov., setae $\mathrm{d} 2$ are situated on the hysteronotal shield (vs. off this shield in C. greenwoodi), the propodonotal and hysteronotal shields each bear five pairs of median setae (vs. 3 and 1 pairs of median setae, respectively), setae $\mathrm{h} 1$ and $\mathrm{h} 2$ are subequal in width to other lateral hysteronotal setae (vs. half the width of other hysteronotal setae).

Andre V. Bochkov [andrevbochkov@gmail.com], Zoological Institute of the Russian Academy of Sciences, Universitetskaya Embankment 1, 199034 Saint Petersburg, Russia; Tyumen State University, 10 Semakova Str., 625003

Tyumen, Russia. Ekaterina A. Sidorchuk [e.a.sidorchuk@gmail.com], Borissiak Paleontological Institute of the Russian Academy of Sciences, Profsoyuznaya 123, 117997 Moscow, Russia.

This is an open-access article distributed under the terms of the Creative Commons Attribution License (for details please see creativecommons.org), which permits unrestricted use, distribution, and reproduction in any medium, provided the original author and source are credited. 